Primljen / Received: 25.4.2017. Ispravljen / Corrected: 26.1.2018. Prihvaćen / Accepted: 23.2.2018. Dostupno online / Available online: 10.4.2018.

\section{Reference water levels for the design of dykes and earthfill dams}

Authors:

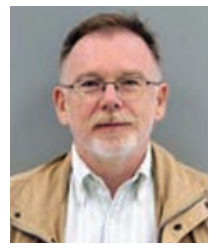

Željko Pavlin, MCE

Elektroprojekt, d.d., Zagreb

zeljko.pavlin@elektroprojekt.hr

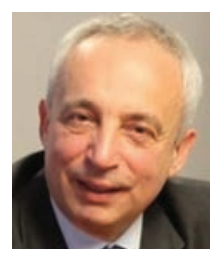

Prof. Neven Kuspilić, PhD. CE

University of Zagreb

Faculty of Civil Engineering

kuspa@grad.hr

\section{Željko Pavlin, Neven Kuspilić}

Subject review

\section{Reference water levels for the design of dykes and earthfill dams}

Various approaches are presented in the paper with regard to the definition of reference water levels for the analysis of functional and structural stability requirements in the design of dykes and earthfill dams of retarding basins and water-storage reservoirs. It should be noted that various methods are used to define reference water levels at the design stage, which results in differing levels of reliability of earthfill dams and dykes. A critical review of current approaches is made, and recommendations are given for a proper approach to the definition of reference flows and water levels for stability analysis.

Key words:

earthfill dam, dyke, reference water level, stability

Pregledni rad

\section{Željko Pavlin, Neven Kuspilić}

Mjerodavni vodostaji za dimenzioniranje hidrotehničkih nasipa i nasutih brana

U radu su prikazani različiti pristupi određivanja mjerodavnog vodostaja za analize funkcionalnih zahtjeva i zahtjeva za stabilnost konstrukcije pri projektiranju hidrotehničkih nasipa i nasutih brana retencija i akumulacija. Ukazuje se na različitu praksu pri određivanju mjerodavnih vodostaja u projektiranju, što rezultira različitom pouzdanošču nasutih brana i hidrotehničkih nasipa. Daje se takođern kritički osvrt na pristupe te donose preporuke za pristup definiranju mjerodavnih protoka i vodostaja za analizu stabilnosti.

Ključne riječi:

nasuta brana, hidrotehnički nasip, mjerodavni vodostaj, stabilnost

Übersichtsarbeit

Željko Pavlin, Neven Kuspilić

\section{Relevante Wasserstände für die Dimensionierung von Aufschüttungen und aufgeschütteten Dämmen}

In der Abhandlung werden unterschiedliche Ansätze für die Bestimmung relevanter Wasserstände für die Analyse funktionaler Anforderungen und Anforderungen an die Stabilität von Konstruktionen bei der Projektierung von hydrotechnischen Aufschüttungen und aufgeschütteten Dämmen der Retention und Akkumulation dargestellt. Hingewiesen wird auf die unterschiedliche Praxis bei der Bestimmung relevanter Wasserstände bei der Projektierung, was eine unterschiedliche Zuverlässigkeit bei den aufgeschütteten Dämmen und hydrotechnischen Aufschüttungen zur Folge hat. Darüber hinaus wird auch ein kritischer Rückblick auf die Ansätze dargelegt, und es werden Empfehlungen für den Ansatz bei der Festlegung relevanter Durchflüsse und Wasserstände für die Analyse der Stabilität gegeben.

Schlüsselwörter:

aufgeschütteter Damm, hydrotechnische Aufschüttung, relevanter Wasserstand, Stabilität 


\section{Introduction}

Dams and dykes are significant for general development of human communities. They offer protection against flooding and meet demands for drinking, irrigation and industrial water supply; they ensure preconditions for the use of water energy, while also increasing flow rates in dry seasons, and creating favourable conditions for various recreational activities.

Other than being a valuable resource, dams and dykes are also a source of risk for downstream areas and the very areas they are protecting, as their failure can cause unacceptable damage to human life and property. Such failure may be due to crest overtopping, and to loss of stability caused by inappropriate selection of reference water levels and inadequate approach to dimensioning of structures. As practical cases of the affected dam and dyke stability have been registered even for the water levels that are below the crest level, the following text focuses on the determination of reference water level to be taken into account for the analysis of:

- Functionality requirements (satisfy purpose)

- Structural requirements (basic structural stability requirements).

As to functionality requirements, the determination of crest levels for dykes and dams is related to the determination of the reference water level on the water face, and to definition of crest freeboard, i.e. the height above a selected reference water level. The reference water level for dykes is defined by the flood occurring over a specified return period, against which a particular area is being protected. As reservoirs and retarding basins dams a reference water level is defined by the necessary or available space to be occupied by the planned reservoir or retarding basin, and by discharhe structure concept for the flood discharge.

With regard to structural stability requirements, a reference water level on the water face determines the load level for the analysis of geotechnical and hydraulic stability. Depending on the solution used in the design of earthfill structures, and dykes in particular, it may be stated that the duration of flood is also quite significant.

The following text focuses on approaches for determining reference water levels in the analysis of functionality and structural stability requirements, as used in Croatia and as recommended in some international design guidelines. These approaches are analysed, and appropriate comments, observations, and standpoints are formulated. This study is based on the analysis of a vast scope of data out of which only the most representative ones are actually presented in this paper.

\section{Functionality requirement - reference water level, and dyke and dam crest freeboard}

\subsection{General}

The dyke and dam crest levels are determined by adding height, the so called freeboard, above the reference water level, which in turn is obtained by computation based on the flow over a particular return period. Definitions of freeboard, varying from country to country, are the subject of this study. Due to differences in approach, a separate account of this issue will be given for:

- dykes

- reservoir dams

- retarding basin dams.

Each of these structures will be analysed separately as the crest level determination is related to determination of a reference water level, and to the determination of the crest freeboard above the reference water level. The freeboard of dykes will not be considered separately because of local conditions involving the influence of culverts and bridges. However, it should be noted that a special attention must be paid to such local zones, as they locally increase the dyke overtopping hazard.

\subsection{Determining dyke crest level}

\subsubsection{Determining reference water level for dykes}

The reference water level is determined on the basis of the reference flood or reference flow over a chosen return period. Two approaches may be used to determine a reference water level [1]:

- Deterministic: a reference event can be determined using either national or regional regulations. A reference water level is the water level defined for a reference flow. It is determined based on the flow - probability correlation and on the water level flow correlation for a given probability that a particular event will occur. A reference return period of one hundred years or more is usually applied (one percent probability).

- Probabilistic: an initial level is usually set first via the deterministic method. The hydraulic calculation is made based on the flow section and hydraulic parameters and, in this respect, the water level is calculated with the 90 or 95 percent reliability for a critical flood event. The calculated level is either confirmed or corrected using the risk analysis that may rely on some form of a Monte-Carlo simulation and is related to the cost-benefit analysis.

An example of deterministic determination of reference water level is the current practice in Croatia where reference water levels have been determined based on the reference flow return periods as specified in the policies and regulations of the Croatian Water Authority (Hrvatske vode), or as set in the terms of reference for a particular project.

A statistical calculation of reference flow for a particular return period, and hence the corresponding water level, is dependent on the length of the series on the basis of which the calculation is being made. Thus, taking into account the requirement to provide for flood protection for a particular return period and a fixed crest freeboard, different levels of the reliability of protection can actually be obtained, depending on the length of the series of available data based on which the reference flow is determined. 
This forecasting uncertainty is also reported in $[2,13]$. Distribution elements are estimated using statistical moments of a sample (average values, standard deviation, asymmetry coefficient). The assumption used in the method is that sample moments correspond well to the population moments of all annual maximum flows.

Over the time, new observations affect the moments and the change in distribution parameters. By analysing statistical moments of the sample, conclusions can be drawn as to actual spreading of population moments. As flow probability function parameters are mathematical functions of moments, a conclusion can be made about such parameters through mathematical analysis. For instance, a conclusion can be made about the bottom and top flow levels which show that the mean parameter of the log Pearson III type has the probability of 0.90 . In other words, the description of uncertainty can be introduced into the frequency function. This approach enables description of uncertainty in the estimation of expected annual flow, and annual probability of its exceedance.

The probabilistic description of the uncertainty of probability of flow can be shown by confidence limits plotted on the flow frequency function diagram, as shown in Figure 1. The limitations shown are the curves that connect the flow or water level for each case of probable exceedance of a calculated value. Figure 1 shows - as an example - the so called 5 and $95 \%$ confidence limits covering the area with the $90 \%$ confidence level. The boundary flow values, which give confidence limits when linked together, can be calculated using an analytic procedure.

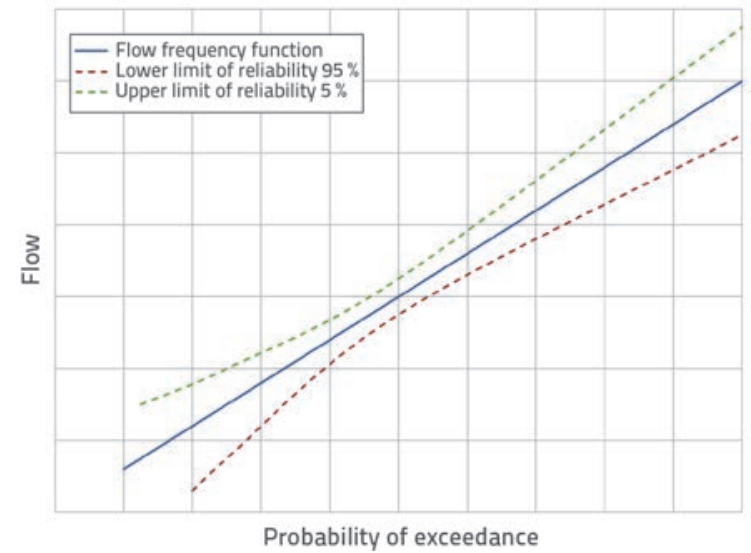

Figure 1. Diagram showing confidence limits related to flow probability

It is also important to note that these statistical analyses are based on the observation of past events. Thus, reference flows determined through statistical analyses, and reference water levels based on such reference flows, are related to the probability of occurrence under conditions that existed in the past. Considering the long service life of dams and dykes, the climate changes or climate variations, and possible changes in drainage areas, influence the change of future conditions as related to the conditions on which statistical analyses are based. In other words, values determined by statistical analyses during the service life of structures are susceptible to changes.
In the scope of development of its flood risk management plan, Croatian Water Authority (Hrvatske vode) has recently startedusing an approach that is based on the development of risk maps. Thus, the approach to protection of a particular area is based on the risk analysis and cost benefit analysis of the protection solution proposed, as reported in [3]. Therefore, a probabilistic approach should be adopted in determination of reference flow rates, and reference water levels in Croatia.

\subsubsection{Determination of freeboard for dykes}

Uniform criteria have not as yet been developed in any country of the world with regard to the design of freeboard above a reference water level. In Croatian practice, the freeboard above a reference water level is determined based on relevant national and international experience, and is specified in planning documents of the Croatian Water Authority, or in the terms of reference for particular projects. At that, although not specifically emphasized, the freeboard includes hydrological and hydraulic uncertainties in the reference water level determination, the influence of wind and waves, the need to cover the core, etc. The addition due to settlement of dykes, when expected to greatly influence the crest level, is calculated through geostatic analyses and is considered separately as an additional freeboard. On the other side, the freeboard value specified in relevant documents is used in cases when significant settlement is not expected.

As uniform criteria for the determination of freeboard are not available, various standards and guidelines are used, or decisions are based on prior freeboard design experience. An overview of available data from international practice [4] shows that, in case of dykes, the freeboard above the reference water level varies from 0.5 to $2.0 \mathrm{~m}$ (Table 1 ).

Table 1. International data for minimum freeboard above reference water level [4]

\begin{tabular}{|c|c|c|c|}
\hline \multirow{2}{*}{ Country } & River & Freeboard [m] & Dyke height [m] \\
\hline \multirow{2}{*}{ Italy } & Mississippi & 0.9 & \\
\cline { 2 - 4 } & Huntington & 1.0 & \\
\cline { 2 - 4 } & Ironton & 0.9 & \\
\hline Pakistan & Po & $0.8-1.0$ & \\
\hline India & Ind & $1.2-1.8$ & $4.0-7.0$ \\
\hline Vietnam & Bed River & 1.0 & 6.0 \\
\hline Myanmar & Irrawady & 1.2 & 7.0 \\
\hline \multirow{2}{*}{ Taiwan } & Pei-Hang & 1.5 & $4.0-9.0$ \\
\hline \multirow{2}{*}{ China } & Hwang-Ho & $1.6-2.0$ & 6.0 \\
\cline { 2 - 4 } & Yang-Tse & 1.0 & 7.0 \\
\hline \multirow{2}{*}{ Philippines } & Agno \& Panpanga & 1.0 & 7.0 \\
\hline Japan & Tone & 2.0 & 8.0 \\
\hline \multirow{2}{*}{ Hungary } & Danube & $0.5-1.0$ & $3.0-5.0$ \\
\cline { 2 - 4 } & Tisa & $1.0-1.6$ & \\
\hline \multirow{2}{*}{ J } & & & \\
\hline
\end{tabular}


In the international practice, the requirement for a fixed freeboard value is gradually being replaced with the requirement that designers should define the crest level based on estimation of the risk and consequences of dyke overtopping, which involves realistic prediction of dyke properties and behaviour (such as, for instance, settlement over time). At that, the following considerations should be taken into account [1]:

- morphological changes occurring over time along the watercourse and possibly influencing the water level

- changes in water level for all return periods that arise from climate changes

- influence of waves and wave run-up on dykes

- settlement of foundation soil and settlement of dyke body

- local or national minimum-freeboard requirements.

If a road is to be built on a dyke, then the road structure elements should also be added to the previously defined crest level.

The principle of priority should also be respected when defining the dyke crest along a watercourse. In fact, longitudinal profile of the crest must be defined in such a way that, in case the water level increases beyond the design level and flooding becomes imminent, the overtopping is restricted to a lowest-risk zone.

\subsection{Determination of dam crest level}

\subsubsection{Determination of reference water level for dams}

The reference water level for reservoirs and retarding basins dams is determined by retaining a specific volume of water in the reservoir or basin, and by designing adequate discharge structures. Water storage requirements are based on requirements formulated by water users (for reservoirs) or requirements relating to protection of downstream areas against flooding (retarding basins), taking into account natural restrictions and limitations due to area development level. Determination of the required volume in reservoirs and retarding basins is the subject of separate analyses and will therefore not be considered in this text. Every water volume in storage reservoirs and retarding basis is defined by an appropriate operating water level. In case of fixed level spillways, the operating water level also defines the spillway crest level. In case of spillways with mobile equipment (gates), the operating water level is often, albeit not always, the maximum water level. Determination of reference water levels in reservoirs and retarding basins, as needed for defining the dam crest level, is based on the dimensioning of discharge structures.

The reference water level, determined by the spillway crest level and determination of discharge structure capacity for reference flood, can be defined - just like in case of dykes - on the basis of two general approaches:

- Deterministic: a reference event may be defined using either national or regional regulations. A reference water level is the water level occurring at the discharge of reference flow, and is defined by spillway dimensioning in case of water storage reservoirs, or by spillway and bottom outlet dimensioning in case of retarding basins. In international practice, this approach is based on the flood wave for a return period that is specified according to dam classification in terms of consequences registered after their failure [58]. This approach is usually conservative as it is considered necessary to ensure an appropriate level of safety and protection of the downstream area.

- Probabilistic: risk analyses are conducted with regard to consequences that may be expected in case of dam failure. The approach involving analysis of incremental consequences may be used when reservoirs are small as related to the volume of water waves that could be expected. In such case the reference water wave can be the water wave in which the consequences for the downstream area are almost identical with or without dam failure.

An official classification of dams according to consequences of their failure has not been put in place in Croatia and, for that reason, the reference flow is not related to the analysis of consequences the dam failure would have on the downstream area. In the current Croatian practice a deterministic approach is generally used for reservoir dams. According to this approach, the reference water level is defined by the spillway crest level and the water level reached at discharge through the spillway in case of a 1000 year flood. According to criterion provided by Nonveiller [9], the maximum water level is defined by the spillway crest level and the water level for the 1000 or 10000 year flood, depending on the population density in the downstream area and the need to increase safety due to possible dam failure. At that, the choice of the return period is left with the designer, i.e. such period is often specified by the client in the terms of reference. The arrival of flood is calculated for a full reservoir. The storage capacity of retarding basin and discharhe structure capacity is determined according to the requirement for transformation of water wave for a particular return period. The return period for water wave to be transformed in the retarding basin has mostly been defined in Croatia by means of the terms of reference. With regard to [3] and as adopted for dykes, this approach is now being modified and involves risk analysis and the use of the cost and benefit analysis. In retarding basin, the reference water level is usually defined in practice by calculating the 1000 year return period water wave for an empty retarding basin. The flood wave is discharged through the bottom outlet and spillway.

When dimensioning retarding basins, it is often times impossible to differentiate between the maximum-flow water wave for a return period, and the maximum-volume water wave for the same return period. When determining storage capacity of retarding basin, it is absolutely necessary to take into account the maximum-volume water wave for a particular return period. In practice, the spillway - and hence also the reference water level - is dimensioned for the water wave volume corresponding to a 1000 return period for an empty retarding basin. This 
Table 2. IDF values dependent on category of dam failure consequences, as used in initial analyses [8]

\begin{tabular}{|c|l|l|}
\hline $\begin{array}{c}\text { Classification according to } \\
\text { consequences of dam failure }\end{array}$ & Description of potential hazard & Reference flood IDF \\
\hline High & $\begin{array}{l}\text { Possible loss of life due to dam failure or error in operation (economic loss, } \\
\text { environmental damage, or failure of life-sustaining facilities may also be } \\
\text { possible, but is not necessary for this classification) }\end{array}$ & $\begin{array}{c}\text { Loss of human life due to dam failure or operation error is not probable, but } \\
\text { may cause economic losses, environmental damage or failure of life-sustaining } \\
\text { facilities }\end{array}$ \\
\hline Significant & $\begin{array}{l}\text { Loss of human life due to dam failure or operation error is not probable, but } \\
\text { some minor economic losses and/or environmental damage are possible }\end{array}$ & 1000 -year flood \\
\hline Low & \multicolumn{1}{|c|}{\begin{tabular}{l}
$100-y e a r$ flood \\
\hline
\end{tabular}}
\end{tabular}

approach can be inadequate as the retarding basin need not necessarily be empty in case of a heavy and brief rainfall giving rise to a water wave of maximum flow corresponding to a 1000 year return period, but whose volume may be much lower. For that reason, when defining a reference water level in a retarding basin, it would be necessary to analyse the water wave:

- whose maximum volume corresponds to a 1000 year return period for an empty retarding basin,

- and the water wave whose maximum flow corresponds to a 1000 year return period for the full retarding basin,

and to determine, based on this information, the reference water level in the retarding basin. The approach related to consequences of dam failure is used worldwide for determining reference flow for the dimensioning of spillways and reference water level in storage reservoirs and retarding basins [5-8]. The basic principle relies on the fact that the dam whose failure may cause great damage and loss in human life is designed with proportionally greater requirements compared to the dam whose failure would cause lesser damage and human casualties. The following terms are used in the guidelines based on ICOLD, FEM and USBR recommendations that serve as basis for defining reference flooding or storage reservoir situations:

- Spillway design flood (SDF): flood event that is relevant for regular spillway operation, its hydraulic design, and for defining characteristics for ensuring the AFC (Acceptable Flood Capacity);

- Dam crest flood (DCF): flood event in which the still water level in storage reservoir is equal to the dam crest level;

- Acceptable flood capacity (AFC): flood capacity required of a dam including freeboard that ensures an appropriate level of safety against critical dam flood-related failure;

- Inflow design flood (IDF): flood that is relevant for the design of the dam and water discharge structures;

- Safety check flood (SCF): extreme flood that the dam has to withstand and still operate safely, with the possibility of smaller damage that can reduce safety but not cause dam failure;

- Annual exceedance probability (AEP): probability that a flood event will be exceeded in any year.

The reference flow, SDF or IDF, is determined within the 100 year return period of a maximum flood event (PMF - probable maximum flood), and the choice is based on the category of dam failure consequences to which the dam belongs. The category is defined according to potential loss of life (PLL) and material losses that could occur as a consequence of dam failure in case of flooding event under consideration. Specified IDF values used in initial analyses are given as an example (Table 2) [8].The example of Queensland, Australia, for small dams including those:

- Less than $12 \mathrm{~m}$ in height,

- Population at risk (PAR) of 15 or less,

- Uncontrolled spillway - no gates,

- Depth of flooding of PAR is less than $3 \mathrm{~m}$, and

- Product of the depth of flooding and flow velocity in the flooded area is less than $4.6 \mathrm{~m}^{2} / \mathrm{s}$,

Is used to establish, via equation (1), a simple function for determining return period for the definition of IDF [5]:

$A E P=\left(\frac{1}{P A R}\right) \cdot 10^{-3}$

An inflow hydrograph for IDF, as used for the analysis of dam and discharge facilities, is determined for the return period defined in this way. A diagram for determining probability of design flood as related to the number of population at risk is provided for this approach (Figure 2).

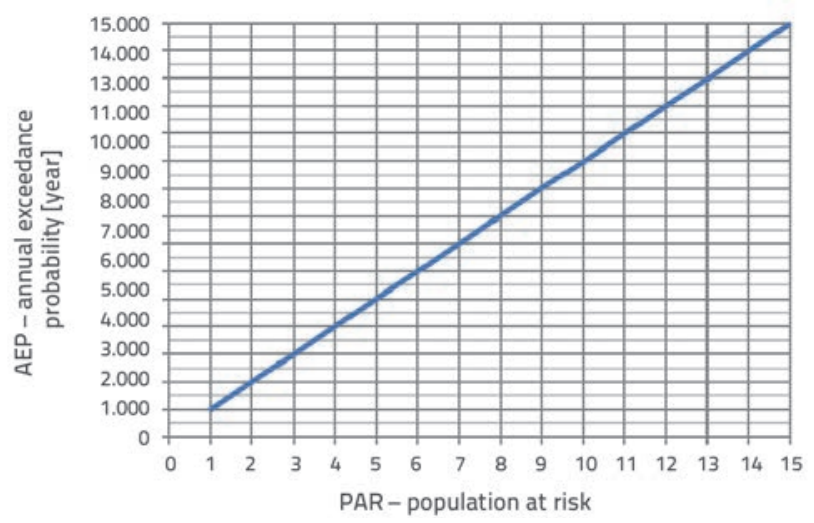

Figure 2. Return period for design flood dependent on PAR

Methods provided in appropriate guidelines of the Australian National Committee on Large Dams (ANCOLD) are used for other cases [6, 7], i.e. for defining the AEP and the inflow hydrograph for the IDF. In 


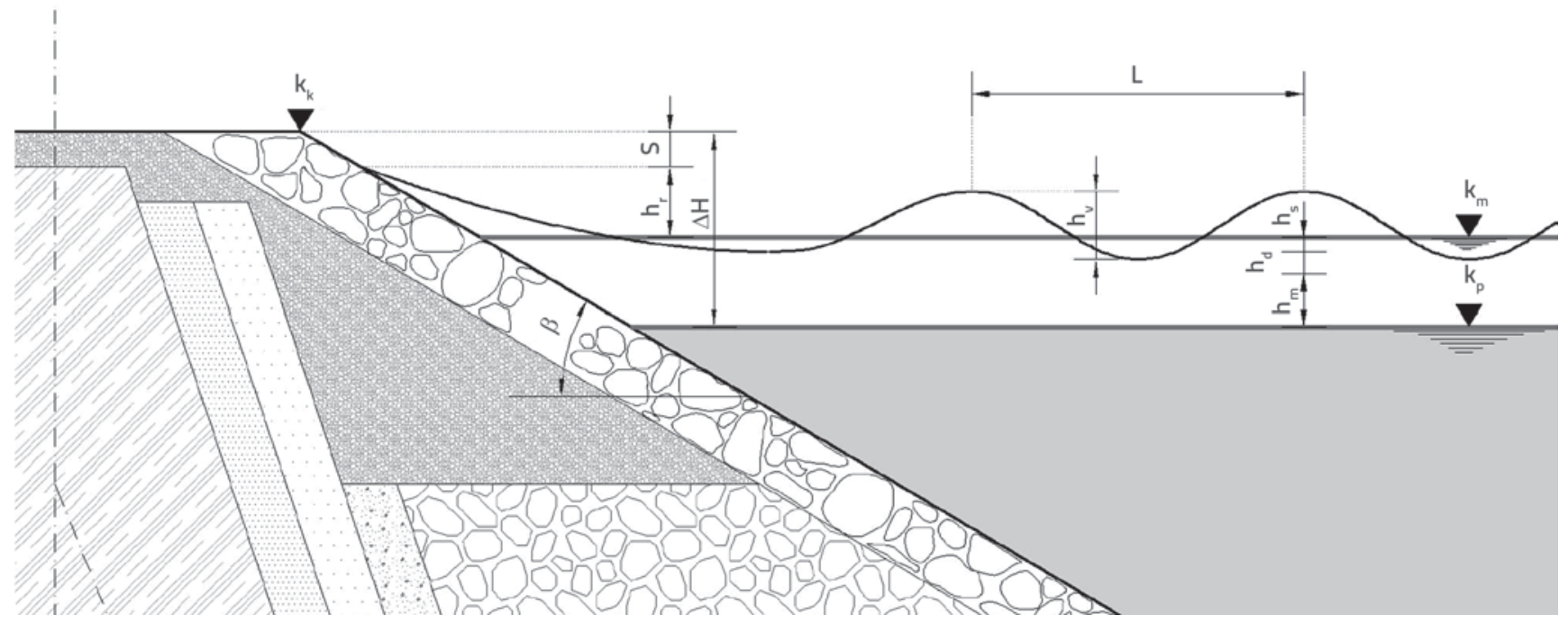

Figure 3. Elements for calculating the dam crest level

international practice, procedures for determining the reference flow vary depending on the area in which they are applied, which is regulated by local guidelines and regulations. These procedures are based on risk analysis and on consequences of damage due to dam failure.

\subsubsection{Determination of freeboard for dams}

Just like in case of dykes, uniform criteria have not been set internationally for the determination of freeboard above a reference water level. The available literature does not mention core-related freeboard i.e. the freeboard above this watertight element of the dam. Instead of that, the freeboard is referred to as the distance between the crest and the reference water level. It would nevertheless be advisable - when defining the freeboard - to take into consideration the dam crest structure above the watertight element of the dam.

The freeboard should be determined on the case-to-case basis taking at that many factors into account, including value of the selected IDF, anticipated duration of flood during IDF, the size of fetch area and storage reservoir characteristics as related to generation of waves, probability of high velocity winds from critical direction, wave run-up along the dam slope as based on the roughness and slope inclination measurements, possibility of spillway capacity reduction due to sediments and/or poor handling, and dam resistance to erosion by overtopping waves. In Croatia, the freeboard of earthfill dams is still defined according to [10] where it is specified that the crest level exceeds the reference water level by the so called "free height" which includes:

- design wave height,

- height of wave run-up along the dam slope,

- additional safety height amounting to 0.5-0.7 m.

At that, according to this standard, the freeboard should not be lower than $1.5 \mathrm{~m}$ for dams of less than $15 \mathrm{~m}$ in height, or $2.0 \mathrm{~m}$ for dams of more than $15 \mathrm{~m}$ in height.
According to [9], which is also applied in practice, the dam crest level $k_{k}$ is defined by the spillway crest level $k_{p}$ and the value $\Delta \mathrm{H}$ that is equal to the sum of (Figure 3 ):

- the height of the overflowing nappe $\left(h_{m}\right)$ above the spillway crest during discharge of reference flood

- height of wave run-up along the slope $\left(h_{r}\right)$ at the highest wind speed in the most unfavourable direction, depending on the water face slope inclination $\beta$, design wave height $h_{v}$ and type of the water face slope material

- increase in reservoir water level $\left(h_{d}\right)$ due to high tide in the direction in which the water is pushed by the wind - this phenomenon can be notable in case of wide and shallow lakes while it is considered negligible in case of small and deep lakes, when it can be included in safety margin

- increase in level due to slow oscillations $\left(h_{s}\right)$ - seiche - as no reliable method exists to determine its size, this value is estimated and included in safety margin

- safety margin $(S)$ from 0.3 to $1.5 \mathrm{~m}$. In seismically active areas, depending on the reservoir size, the safety margin ranging from 1.5 to $3.0 \mathrm{~m}$ is recommended.

At that, the choice of reference flood return period for nappe calculation is not linked to the probability of occurrence in the design life span, but is normally selected by the designer, or specified in the terms of reference. The probability of occurrence of the strongest wind is not defined during determination of the design wave height. The direction, velocity, and frequency of wind are variable and depend on the morphology of the valley in which the water body is located, and the wind data are registered at weather stations that are usually quite distant from the locality. That is why the reliability of wave height determination, which greatly influences definition of freeboard, can also be considered.

Jansen [11] reports that the freeboard criterion varies and that one of the criteria for high-risk earthfill dams is the possibility of PMF discharge, or that it can withstand maximum 
Table 3. Return periods for characteristic and design water levels, depending on design life of the structure

\begin{tabular}{|c|c|c|}
\hline $\begin{array}{c}\mathbf{n} \text { - design life } \\
\text { [years] }\end{array}$ & $\begin{array}{c}\text { Return period } \mathbf{p}_{\mathrm{d}} \text { for characteristic water level } \mathbf{H}_{\mathbf{k v}} \\
\text { (probability of exceedance over design life } \mathbf{P = 5 0} \text { ) }\end{array}$ & $\begin{array}{c}\text { Return period } \mathbf{p}_{\mathrm{d}} \text { for design water level } \mathbf{H}_{\mathrm{pv}} \\
\text { (probability of exceedance over design life } \mathbf{P}=\mathbf{1} \text { ) }\end{array}$ \\
\hline 10 & 15 & 1.000 \\
\hline 50 & 75 & 5.000 \\
\hline 100 & 150 & 10.000 \\
\hline 120 & 180 & 12.000 \\
\hline
\end{tabular}

earthquake without crest overtopping. Analyses based on ICOLD recommendations [14,15], as reported in [13], show that dam design should be based on SCF with reservoir water level close to dam crest level.

In this respect, an additional criterion for the determination of the dam crest level is often used in our practice. According to that criterion, the dam crest level must not be lower that the reservoir water level the 10000 year flood event and, for retarding basins, the crest level must not be lower that the water level achieved at safe discharge of flood wave corresponding to the 10000 year return period, for the case of an empty retarding basin.

The freeboard due to dam settlement is calculated using geotechnical analysis. It is estimated as an additional height to the crest level, corresponding to the expected settlement [10].

\section{Structural stability requirements - determination of reference water level for hydraulic and geotechnical stability analysis}

The water level obtained as reference value for meeting functionality requirements, i.e. the water level that defines, together with freeboard, the dam crest or dyke crest level, is usually also considered in Croatia as the reference value for the analysis of hydraulic and geotechnical stability of dams and dykes.

Such selection of water level for stability analyses can be in contradiction with elements that are used for dam freeboard definition. Thus, if the dam freeboard definition includes uncertainties related to hydraulic and hydrological analyses for determination of water level relevant for fulfilling functionality requirements, then the water level in reservoir should be increased at least for the value covering such uncertainties.

Water levels relevant for dyke and dam stability analyses do not need to be, and are actually not identical to water levels based on which their crest level is determined.

Considering the long service life of dykes and dams it is also necessary to take into consideration, during definition of reference water level for stability analyses, the probability of its exceedance over the design service life [13-15] as well as the duration of flood in case of dykes. During stability analysis of dykes and earthfill dams, it is necessary to select the case whose probability of occurrence is very small over the design life of the structure under study. The probability $(P)$ of exceedance of an event, with the probability of occurrence $\left(p_{d}\right)$ over a design life $(n)$, is represented by the following equation:
$P=1-\left(1-p_{d}\right)^{n}$

where $p_{d}$ is the probability of occurrence of an event in any year, $n$ is the design life in years, and $P$ is the probability of exceedance of the event under study over the design life of the structure. The following values are defined for stability analysis [12]:

- characteristic water level, $H_{k v^{\prime}}$ the least favourable water level that will probably occur for a design situation

- design water level, $H_{p u^{\prime}}$ the least favourable water level that can occur for a design situation

Characteristic water level is usually defined as the water level with the return period not shorter than that defined for the structure, i.e. according to [12] the value of $H_{k v-50 \%}$ is recommended, which is the water level with no more than $50 \%$ probability of exceedance over the design life of the structure. For this case, it is recommended to conduct the analysis of mechanical resistance and stability by using partial load factors.

According to [12], the design water level should be $H_{k v-50 \%}$ - which is the water level with no more than $1 \%$ probability of exceedance over the design life of the structure. The analysis of mechanical resistance and stability is anticipated without the use of partial load factors.

The case with greater load is relevant in the analysis of hydraulic stability. The design water level without partial load factors is relevant in the analysis of geotechnical stability, i.e. in the analysis of ultimate limit state (ULS), which is the state followed by structural failure that puts into jeopardy the safety of people and goods.

Based on equation (2), the return periods for characteristic and design water levels, depending on design life, are provided for the above mentioned recommendation regarding probability of exceedance over the design life (Table 3, Figure 4).

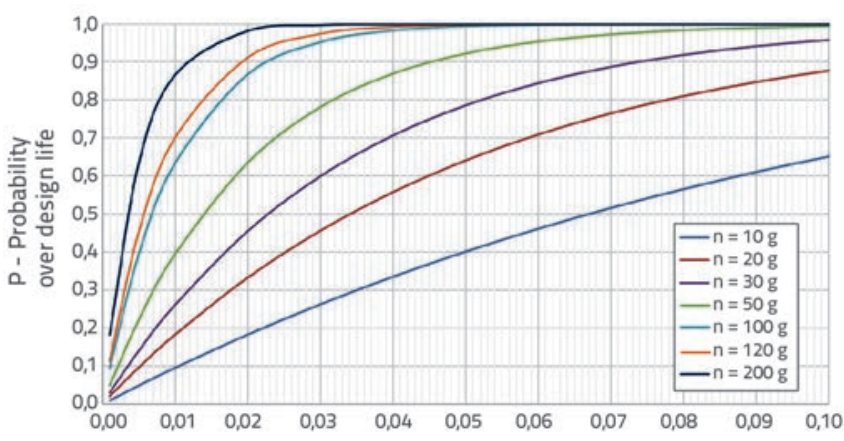

Figure 4. Correlation between probability of occurrence in any year and probability of occurrence of event over time 
Based on the above mentioned information, the proposal is given below for determining $H_{k v}$ and $H_{p v}$ based on the design situation determined by the design water level, as defined by functionality requirements and freeboard.

Thus the analysis of mechanical resistance and stability should be conducted for the water level equal to $H_{p v-1 \%}$ (Figure 5a) during analysis of mechanical resistance and stability for dykes and dams whose crest level is higher than $H_{p v-1 \%}$. When conducting analysis of mechanical resistance and stability for dykes whose crest level should be lower than $H_{p v-1}$ \% because of the proven need for a lower level of protection, the analysis of mechanical resistance and stability should be conducted for the water level of $H_{p v}$ at the crest level (Figure 5b). In case the possibility of protecting the structure by temporary embankments is anticipated so as to increase the level of protection, a higher water level $H_{p v}$ should be taken into account in the calculation of mechanical resistance and stability of the dyke to provide for the placement of these temporary embankments (Figure $5 c$ ).
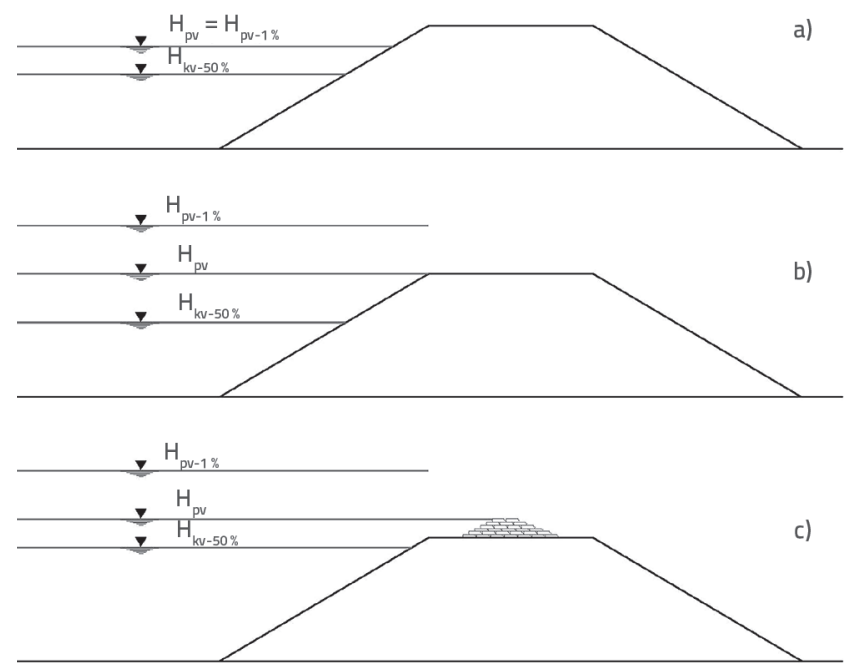

Figure 5. Water levels relevant for stability analysis for various design situations

Based on experience gained in the case of discharge of the catastrophically flood at the Oroville Dam in California when the problem with the stability of discharge structures was experienced, it would be necessary to ensure, in the case of dams, a safe discharge of water even for the design flood levels, i.e. for the return period of no less than $1 \%$ probability of exceedance over the design life, on no less than 100 years, and to also conduct for such case the analysis of stability of discharge structures.

\section{Conclusion}

The following two requirements have to be met in design dykes and earthfill dams:

- functionality requirement (satisfy the purpose of the structure),
- structural requirement (basic structural requirements), which consequently also implies the need to define two reference water levels. In this respect, the reference water level related to functionality requirements can be differentiated from the reference water level for the determination of mechanical resistance and stability of the structure. Water levels related to meeting functionality requirements arise from the analysis of the need to protect a particular area. On the other hand, water levels that are used for the analysis of mechanical resistance and stability of structures represent predictable loads that can act on the structure and that do not cause its failure, nor unacceptable deformations or damage that is disproportionate to the cause.

When defining reference water level values, the following structures have to be differentiated to take into account their specific conditions and requirements: reservoir dams, retarding basin dams, dykes.

Various approaches - dependent on intended occupancy - are used in Croatia and elsewhere in the world for meeting storage reservoir functionality requirements with regard to useful storage of such reservoirs. However, for the reference water level, derived from reference flood that determines the dam crest level, there is no national regulations or guidelines, but only design experience.

In accordance with relevant Directive [3], the current approach relying on administrative determination is being changed, and the approach based on risk analysis is currently introduced, with regard to definition of retarding basin volume and determination of water level relevant for meeting functionality requirements for dykes, as they form part of the flood defence system. When defining reference water level for determining dam crest for retarding basins, the situation is identical to the one regarding reservoir dams.

Considering the long design life of dykes and dams, reference water level must be determined, for stability analysis purposes, according to the probability of its exceedance over the design life. If such approach is not possible, regardless of the reason, then an addition must be determined with regard to the reference water level as a means for meeting functionality requirements. After that, the stability analysis has to be conducted based on such increased state. This addition should at least cover uncertainties that may influence possible raise in water level and possible events during the service life, such as placing temporary embankments on the crest.

Determination of reference flood, as a basis for determining the reference water level, is based on statistical analysis of past series. At that, the length of the series used in the analyis greatly influences reliability of results and, hence, the reliability analysis should be conducted. Considering the long design life of dams and dykes, climatic changes or variations influence the change of future conditions as related to conditions on which statistical analyses are based, which is why the values determined through statistical analyses 
during service life are susceptible to changes. For that reason, the need arises for introducing control mechanisms for reference floods and reference water levels, and possibly for introducing measures for adjustment to new conditions in the course of service life.

In addition to changes of climatic conditions, the long design life can also bring about changes in situation downstream of the dam due to subsequent construction and use of space. Thus the level of risk the dams and dykes impose on downstream areas also changes in time. Control calculation must therefore be anticipated in this segment as well and, if necessary, appropriate adjustments must be provided for in order to maintain the necessary level of safety in downstream areas.

\section{REFERENCES}

[1] CIRIA: The International Levee Handbook (ILH), CIRIA, London, 2013.

[2] Griffin, R.H.: EM1110-2-1619 - Engineering and Design, Risk based analysis for flood damage reduction studies, Department of Army, U.S. Army Corps of Engineers, Washington, DC, 1996.

[3] Direktiva 2007/60/EC Europskoga parlamenta i vijeća o procjeni i upravljanju poplavnim rizicima, Službeni list Europske unije, L 288/27.

[4] Framji, K.K.: Manual of Flood Control Methods and Practices, International Commission on Irrigation and Drainage, Delhi, 1983.

[5] DEWS: Guidelines on Acceptable Flood Capacity for Water Dams, State of Queensland, Department of Energy and Water Supply, Australia, 2013.

[6] ANCOLD: Guidelines on Dam Safety Management, Australian National Committee on Large Dams, Australia, 2003.

[7] ANCOLD: Guidelines on Selection of Acceptable Flood Capacity for Dams, Australian National Committee on Large Dams, Australia, 2000.
[8] FEMA: Selecting and Accomodating Inflow Design Floods for Dams, Federal Emergency Management Agency, 2013.

[9] Nonveiller, E.: Nasute brane, projektiranje i građenje, Školska knjiga, Zagreb, 1983.

[10] HRN U.C5.020/80 - Projektiranje nasutih brana i hidrotehničkih nasipa, Tehnički uvjeti.

[11] Jansen, R.B.: Advanced Dam Engineering, Van Nostrand Reinhold, New York 1988

[12] Pickles, A., Sandham, S., Simpson, B., Bond, A.: Application of Eurocode 7 to the design of flood embankments, CIRIA, London, 2014.

[13] Lemperiere, F., Vigny, J.P.: Shall we forget the traditional design flood?, Hydropower\&Dams, 12 (2005) 2, pp. 140-147

[14] ICOLD: Bulletin 82; Selection of Design Flood, 1992.

[15] ICOLD: Bulletin 125; Dams and Floods, 2003. 